\title{
Effect of Integrated Financial Management Information System on Public Expenditure Management in Kenya
}

\author{
Dr. Michael Njoroge Njogo ${ }^{1} \quad$ Boniface Gitonga Njeru ${ }^{2}$ \\ 1. Lecturer, School of Business, KCA University \\ 2. Senior Auditor, Treasury
}

\begin{abstract}
Kenyan public sector has been recording an increase in the misuse of public funds through fraud and corruption over the years. Public expenditure amounting to Kshs.66.7 billion incurred for the financial year 2013/14 was not fully accounted for and a further Kshs.24.5 billion unapproved excess expenditure. This represents $4.6 \%$ and $1.7 \%$ respectively of the actual net expenditure of that financial year. The unaccounted amount was due to expenditure in the government without adequate authentication. Part of the excess expenditure was also due unapproved utilization of public expenditure in various ministries. Misuse of public funds has been derailing government service delivery and economic development. If integrated financial management information system (IFMIS) was fully operational and its components interlinked, it would ensure transparency and accountability in all the public units, that is, procurement, budgeting and accounting. This would enhance expenditure management in public sector if the three systems are well coordinated. Automating and linking these processes would result to a sound public finance management since managers in each unit can communicate easily in case a fraud is detected in the system. The linking of the three modules would also improve on public expenditure management since each unit will stick and adhere to the itemized budget estimate without diversion of finances to other unplanned expenditure. This study sought to establish the effect of electronic procurement, electronic budgeting and automated cash management on public expenditure management in Kenya. The study adopted descriptive research design and the target population was 140 respondents drawn from five ministries in the National Government. Primary data collected using a structured questionnaire was coded and analyzed using multiple regression analysis and correlation analysis. The study found out that there is a significant positive relationship between electronic procurement, electronic budgeting, automated cash management and public expenditure management in Kenya. According to the study findings, Kenyan IFMIS modules are inadequately interlinked and this creates a loophole for fraud and misuse of public funds. This study recommends the linking of the electronic procurement, electronic budgeting and cash management modules so as improve on public expenditure management since each unit will stick and adhere to the itemized budget estimate without diversion of finances to other unplanned expenditures.

Keywords: Electronic Procurement, Electronic Budgeting, Automated Cash Management, Public Expenditure
\end{abstract} Management in Kenya.

DOI: $10.7176 / \mathrm{IKM} / 12-1-01$

Publication date: January $31^{\text {st }} 2022$

\section{Introduction}

Integrated financial management information system (IFMIS) is a system used to support management of public sector's budgetary, financial and accounting operations. IFMIS helps in promoting better public financial management since it has a centralized registry of public sector revenues and expenditures. It also integrates budgetary, accounting, treasury and public debt management processes in one system (Hendricks, 2012). Successful implementation and linking of IFMIS modules produces timely, relevant and reliable financial data which can be used to promote fiscal discipline, assist with resource allocation, improve operational efficiency and fiscal transparency. IFMIS, therefore, constitute a powerful tool for enhancing public financial management of a country (and other levels of government), although it tends to be complex and demand significant human and financial resources (Allen, Heurtebise \& Tumbull, 2010).

IFMIS enables an organization to report their transactions in real time. This gives the management immediate status to prevent occurrence of losses due to delayed decision making process (Allen, Heurtebise \& Tumbull, 2010). According to Dodd (2010), public financial management (PFM) reforms improve the economy in various sectors as it strengthens regulations, transparency and accountability. PFM reforms initiatives have been supported by various development partners who have worked closely with the developing countries to reinforce their financial information system which enhances consumer protection.

In China, IFMIS was initialized in 2010 by the ministry of finance to enhance advanced financial accounting for transparency and accountability. The accrual accounting system was further improved in 2014 through publication of the fiscal and tax system reform plan which aimed at implementing a systematic public finance management reforms in China. According to Hang (2015), the idea of introducing a management system based on results in United Kingdom public sector was in place since 1980s and its aim was to enhance efficiency in public expenditure and to ensure value for money. 
South Africa implemented IFMIS through its National Treasury. Its aim was to automate government procedures for effective overall management and financial performance of the public sector (Hendricks, 2012). The implementation was carried out in three phases of master system planning, development and implementation. In Kosovo the implementation of IFMIS was successful and the donors like CIDA, SIDA and USAID played a very big role. The process of rolling out the program included system demonstration for functionality to future users of the system, the senior managers and other staffs trainings. The system was rolled out to other governmental areas but it later started to face political challenges especially for the municipalities (Hodess, 2009).

For efficient implementation of IFMIS in Nigeria, there was a need to have a strong monitoring criteria since this would eradicate malpractices in the public sector, improve on transparency and accountability on expenditures (Ibrahim \& Dauda, 2014). In Tanzania IFMIS was introduced in 1994 but it was implemented in various government agencies in 1998 (Robin, 2009). Tanzanian's IFMIS is less complex since it has a medium size management and accounting package. The roll-out plan was initiated based on the incremental approach which was done in accountant general department among other ten government ministries, then to all other ministries and departments (Robin, 2009).

In Kenya, IFMIS was introduced in 1998 but it was implemented in various government ministries in 2003. It was further extended to the county governments in 2012 through the IFMIS re-engineering process to improve the financial system (Kinyeki, Kipsang \& Peterson, 2008). The implementation was spearheaded by the National Treasury to improve on the soft issues bid evaluation tool (SIBET) and enterprise resource planning (ERP) systems which were previously used as a financial management system (Imbuye, 2013). Implementation of IFMIS in national and county governments was aimed at improving the financial management in the public sector, through enhanced transparency, accountability and cost saving (Karanja \& Ng'ang'a, 2011).

Kenyan public sector has been recording an increase in the misuse of public funds through fraud and corruption over the years. Public expenditure amounting to Kshs.66.7 billion incurred for the financial year 2013/14 was not fully accounted for and a further Kshs.24.5 billion unapproved excess expenditure. This represents $4.6 \%$ and $1.7 \%$ respectively of the actual net expenditure of that financial year. The unaccounted amount was due to expenditure in the government without adequate authentication. Part of the excess expenditure was also due unapproved utilization of public expenditure in various ministries. Misuse of public funds has been derailing government service delivery and economic development (Auditor General, 2015).

If IFMIS was fully operational and all modules integrated, it would ensure transparency and accountability in all the public units, that is, procurement, budgeting and accounting. This would further enhance expenditure management in Kenyan public sector (Ngibuini, 2005). Automating and linking these processes would result to a sound public finance management since managers in each unit can communicate easily in case a fraud is detected in the system. The linking of the three modules would also improve on public expenditure management since each unit will stick and adhere to the itemized budget estimate without diversion of finances to other unplanned expenditures (Muigai, 2012).

Njonde and Kimanzi (2014) studied the effectiveness of IFMIS on the performance of the public sector in Kenya while Chado (2015) evaluated the effect of IFMIS on the financial management in Kenya. Odoyo et al (2013 noted that implementation of IFMIS in Kenya was hampered by its complications, security and reliability issues limiting cash management process. These studies only analyzed budgeting and cash management component of accounting module without considering the other modules of IFMIS. This study sought to establish the effect of electronic procurement, electronic budgeting and automated cash management on public expenditure management in Kenya.

This study is structured as follows: Chapter one provides the background of the study, statement of the problem and the research objectives. Chapter two presents relevant theoretical review and the conceptual framework. Chapter three provides details on the research design, target population, empirical modeling and data analysis while Chapter four covers data analysis results, presentations and discussions. Finally, Chapter five provides a summary of findings, conclusion, recommendations and suggested areas of future studies.

\section{Literature Review}

\section{Innovation Diffusion Theory}

This theory was proposed by Rodgers (1962) and it focuses on understanding how, why and at what rate innovative ideas and technologies spread in a social system (Rogers, 1962). The theory sees change as being primarily about the evolution of products and behaviours so they become better fits for the needs of an individual (s). It is not people who change, but the innovations themselves (Les Robinson, 2009). Diffusion is the process by which an innovation is communicated through certain channels over time among the members of a social system (Rogers, 2003). Rogers (2003) identified three adoption stages which include initiation, adoption and implementation. Further Rodgers argued that innovations and products with greater compatibility and simplicity have high chance of adoption, easy implementation and usage. The decision to adopt an innovation relies on social system perception and the attributes of innovation which include; compatibility, complexity and piloting of the system. The adoption 
process is complex since different individual categories are involved (Gounaris \& Koritos, 2008).

At firm level, a manager would play a big role in the whole process of implementing an innovative product. The internal structure of the firm also play a key role in the adoption of innovations due to the expertise level of the individuals. Also, external factors of the firm contribute to the level of the whole system adoption (Rogers, 1995). The theory according to Rogers (1962) perceives that any advancement in technology is adopted in a firm's channels at a certain social system depending on its employee's motivation. According to Li (2008), the major strategy in adoption of an electronic procurement is to full implementation automated procurement procedures. This enables the management to have adequate controls on the entire procurements process. IFMIS in Kenya was an innovation adopted to improve the public service and curb misappropriation of funds in the government. Consequently, this required some adoption criteria for it to be acceptable by the government officials. This theory enables the researchers in studying the adoption of IFMIS modules in the Kenyan public sector.

\section{Instrumental Theory}

This theory was developed by Bailey (1968) and it focuses on how well the public sector can use other budgeting systems in resource allocation to the overall budget execution. The theory articulates that the allocation of resources can improve managerial capacity toward budgetary processes in the public sector. According to Pettijohn and Grizzle (1997), an alternative overall budgeting system controlled by the public sector is not biased by the policy process. The theory lays a foundation on how allocations are made in the public sector.

Walker (1930) affirms that an organized and theoretically based knowledge are important during the budgetary decision making. The aim of the management in any organization includes system implementation and ensuring that their staffs are satisfied with the system adopted so as to improve organizational performance through the use of an automated budgeting system. The aim of the management in any organization includes system implementation and ensuring that their staffs are satisfied with the system adopted so as to improve organizational performance through the use of an automated budgeting system (Raja \& Baral, 2015). The theory helps in understanding how integrated budgeting system can be used to curb misuse of public funds.

\section{Unified Theory of Acceptance and Use of Technology (UTAUT)}

UTAUT was developed by Davis, Fred, Gordon, Michael, Morris, Venkatesh and Viswanath (2003) to merge competing information technology acceptance models. Driven by a motivation to unify research efforts in Technology literature, UTAUT was introduced and developed based on eight technology acceptance competing models. These models and theories are technology acceptance model (TAM), theory of reasoned action (TRA), theory of planned behavior (C-TAM-TPB), motivational model (MM), theory of planned behavior (TPB), a model combining the technology acceptance model and the model of PC utilization, innovation diffusion theory (IDT) and social cognitive theory (SCT).

The theory was established on four theoretical constructs representing determinants of intention to use (usage behavior), which play essential roles as surrogates of technology acceptance. These constructs are: performance expectancy, effort expectancy, social influence, and facilitating conditions. In addition to these variables the theory considers also moderating factors which moderate the relations between various variables and intention to use. The moderators are gender, age, experience and voluntariness of use (Davis et al., 2003).

Due to increased use of information technology in various organizations, there is need for ICT to be accepted so as to improve productivity of the employees in all sectors (Westland \& Clark, 2000). The theory addresses four major sub-theories; performance expectancy which states that an individual believes new innovation can improve one's overall performance, effort expectancy theory, which measures extent at-which an individual believes that the innovation can be used easily. Third theory is social influence, where one makes assumption that those around should be in the frontline during implementation of information system innovations.

The model is useful on the introduction of accounting information systems in an organization as it incorporates various variables influencing the individual reactions on information technology. Therefore, basic concepts in user acceptance to the new technology include; Individual reactions in using the information technology, the intention to use it and the actual use of the technology (Davis et al., 2003). ICT implementation and its success require various approaches and strategies (Yonazi, 2010). The theory addresses the level of acceptance of IFMIS in Kenya

\section{Conceptual Framework}

A conceptual framework shows the relationship between the dependent and independent variables of the study (Orodho, 2008). The dependent variable is one which the researcher aims to explain in a study. The dependent variable of the study was public expenditure management while the independent variables were IFMIS procurement module, IFMIS budgeting module and IFMIS accounting module. These are presented in figure 1 below. 


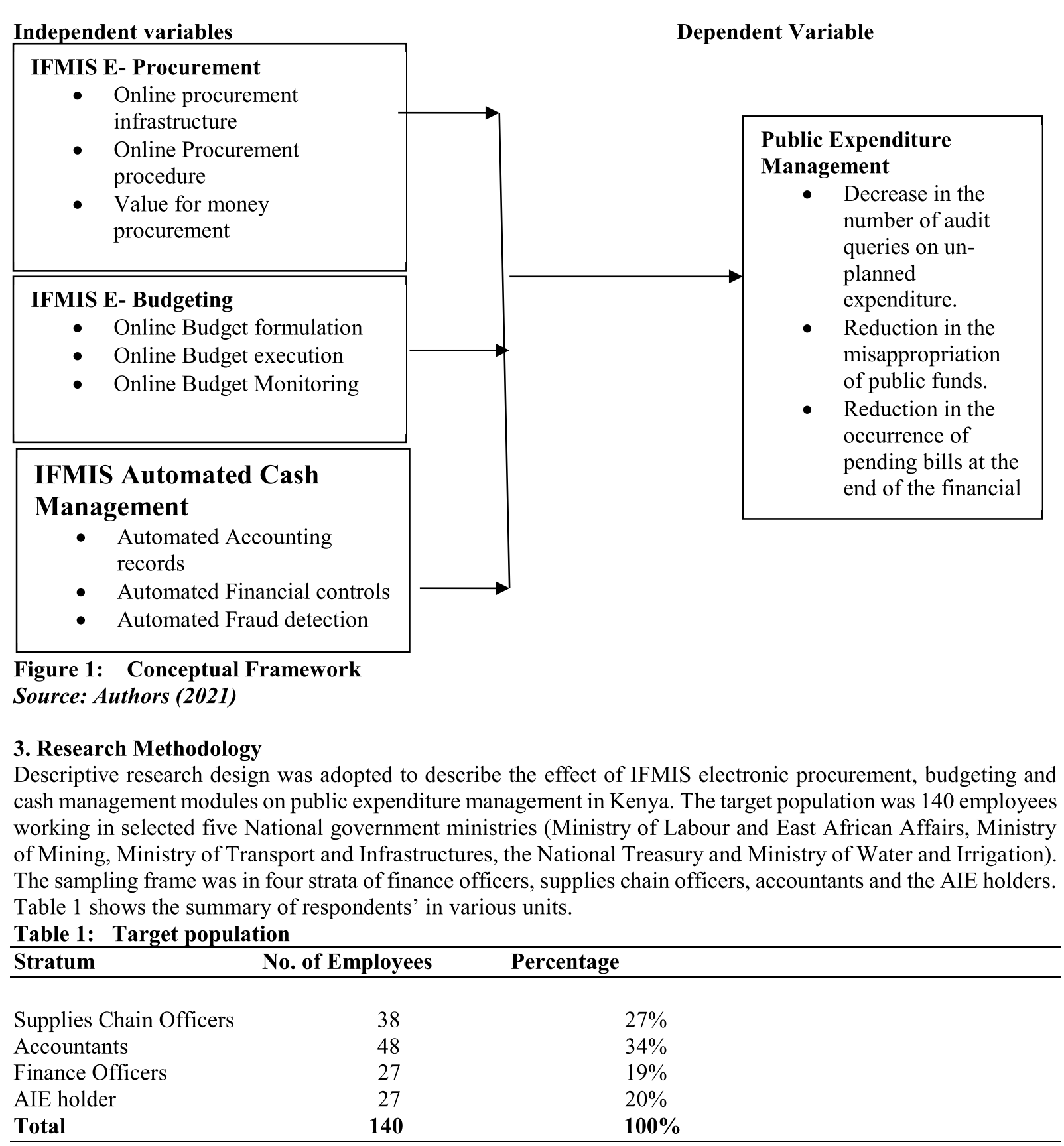

Source: Human Resource (2021)

Primary data collected using structured questionnaires was coded and analyzed using correlation analysis and multiple regression analysis. The multiple regression analysis model was specified as follows; $Y=\beta_{0}+\beta_{1} X_{1}+\beta_{2}$ $X_{2}+\beta_{3} X_{3}+\varepsilon$ where, $Y$ is the dependent variable (public expenditure management), $\beta_{0}$ is the constant/ intercept, $\beta_{1}, \beta_{2}, \beta_{3}$ are the Beta coefficients of independent variables $X_{1}, X_{2}$ and $X_{3}$ (representing IFMIS procurement module, IFMIS accounting module and IFMIS budgetary module respectively) and $\varepsilon$ is the error term.

\section{Results and Discussions}

\section{Correlation between IFMIS and Public Expenditure Management}

The correlation between IFMIS and Public Expenditure was tested using Pearson's coefficient of correlation (r) and probability value ( $\mathrm{p}$-value) analysis. A correlation was considered significant when the resulting $\mathrm{p}$-value was equal to or below 0.05 ( $\mathrm{p}$-value $\leq 0.05$ ). Correlation values ( $\mathrm{r}$ ) close to zero meant a weak relationship and $\mathrm{r}$ close to one meant a strong correlation existed. Table 2 results indicates that there is a significant positive relationship between electronic procurement, electronic budgeting, automated cash management and public expenditure management at 0.05 level of significance. 
Table 2: Correlation between IFMIS and Public Expenditure Management

\begin{tabular}{|c|c|c|c|c|c|}
\hline & & $\begin{array}{l}\text { Electronic } \\
\text { Procurement }\end{array}$ & $\begin{array}{l}\text { Electronic } \\
\text { Budgeting }\end{array}$ & $\begin{array}{l}\text { Automated Cash } \\
\text { Management }\end{array}$ & $\begin{array}{l}\text { Public } \\
\text { Expenditure } \\
\text { Management }\end{array}$ \\
\hline $\begin{array}{l}\text { Electronic } \\
\text { Procurement } \\
\text { Module }\end{array}$ & $\begin{array}{l}\text { Pearson } \\
\text { Correlation } \\
\text { Sig. (2-tailed) } \\
\mathrm{N}\end{array}$ & 103 & $\begin{array}{l}.708^{* *} \\
.000 \\
103\end{array}$ & $\begin{array}{l}.689^{* *} \\
.000 \\
103 \\
\end{array}$ & $\begin{array}{l}.709^{* *} \\
.000 \\
103\end{array}$ \\
\hline $\begin{array}{l}\text { Electronic } \\
\text { Budgeting Module }\end{array}$ & $\begin{array}{l}\text { Pearson } \\
\text { Correlation } \\
\text { Sig. (2-tailed) } \\
\text { N }\end{array}$ & $\begin{array}{l}.708^{* *} \\
.000 \\
103 \\
\end{array}$ & $\begin{array}{l}1 \\
103 \\
\end{array}$ & $\begin{array}{l}.725^{* *} \\
.000 \\
103 \\
\end{array}$ & $\begin{array}{l}.806^{* *} \\
.000 \\
103\end{array}$ \\
\hline $\begin{array}{l}\text { Automated Cash } \\
\text { Management } \\
\text { Module }\end{array}$ & $\begin{array}{l}\text { Pearson } \\
\text { Correlation } \\
\text { Sig. (2-tailed) } \\
\mathrm{N}\end{array}$ & $\begin{array}{l}.689^{* *} \\
.000 \\
103 \\
\end{array}$ & $\begin{array}{l}.725^{* *} \\
.000 \\
103 \\
\end{array}$ & $\begin{array}{l}1 \\
103 \\
\end{array}$ & $\begin{array}{l}.774^{* *} \\
.000 \\
103 \\
\end{array}$ \\
\hline $\begin{array}{l}\text { Public } \\
\text { Expenditure } \\
\text { Management }\end{array}$ & $\begin{array}{l}\text { Pearson } \\
\text { Correlation } \\
\text { Sig. (2-tailed) } \\
\text { N }\end{array}$ & $\begin{array}{l}.709^{* *} \\
.000 \\
103\end{array}$ & $\begin{array}{l}.806^{* *} \\
.000 \\
103\end{array}$ & $\begin{array}{l}.774^{* *} \\
.000 \\
103\end{array}$ & $\begin{array}{l}1 \\
103\end{array}$ \\
\hline
\end{tabular}

**. Correlation is significant at the 0.05 level (2-tailed).

\section{Source: Authors (2021)}

\section{Multiple Regression Analysis}

The study adopted the use of multiple regression analysis in testing the effect of IFMIS on public expenditure management. Guided by the assumption of linear relationship IFMIS and Public Expenditure Management, the study used the Ordinary Least Square (OLS) method of estimation to extract a regression line that provided the best fit. The summary of the regression output is presented in table 3 below.

Table 3: Multiple Regression Analysis Output

\begin{tabular}{|ll|l|l|l|l|l|}
\hline \multirow{2}{*}{ Model } & \multicolumn{2}{|l|}{$\begin{array}{l}\text { Unstandardized } \\
\text { Coefficients }\end{array}$} & $\begin{array}{l}\text { Standardized } \\
\text { Coefficients }\end{array}$ & t & \multirow{2}{*}{ Sig. } \\
\cline { 3 - 5 } & B & Std. Error & Beta & & \\
\hline & (Constant) & 0.674 & 0.272 & & 2.479 & 0.015 \\
Electronic Procurement & 0.201 & 0.092 & 0.187 & 2.181 & 0.032 \\
Electronic Budgeting & 0.421 & 0.077 & 0.454 & 5.435 & 0.000 \\
& Automated Cash Management & 0.270 & 0.087 & 0.278 & 3.111 & 0.002 \\
\hline
\end{tabular}

\section{Source: Authors (2021)}

The multiple regression analysis model was fitted as follows

$\mathrm{Y}=0.674+0.201 \mathrm{X}_{1}+0.421 \mathrm{X}_{2}+0.270 \mathrm{X}_{3}$ where $\mathrm{Y}$ represented public expenditure management, 0.674 is the constant in the estimated model showing the public expenditure management levels in the absence of the IFMIS modules, $\mathrm{X}_{1}, \mathrm{X}_{2}$ and $\mathrm{X}_{3}$ are the independent variables representing procurement module, budgetary module and automated cash management module respectively. The results indicate that electronic procurement, electronic budgeting and automated cash management have a significant positive effect on public expenditure management in Kenya since all their P-values $(0.032,0.000$ and 0.002$)$ are less than the 0.05 level of significance.

From the fitted model, it is evident that a unit change in electronic procurement would result in 0.201 units change in public expenditure management while a unit change in electronic budgeting would result in 0.421 units change in the public expenditure management. It is further shown that a unit change in automated cash management would lead to 0.27 units change in public expenditure management in Kenya. The results indicate that electronic budgeting had the greatest influence on public expenditure management, followed by automated cash management and finally electronic procurement.

\section{Summary of findings, Conclusion and Recommendations Summary of findings}

It was established that electronic procurement module has a significant effect on public expenditure management in Kenya. Linking of electronic procurement with the other IFMIS modules can help to reduce unplanned procurement and enhance transparency in the procurement process. Electronic procurement in public institutions can played a big role in reducing anomalies through good governance in procurement sector which promotes public 
expenditure management. Electronic budgeting has a significant influence on public expenditure management in Kenya. By linking of the electronic budgeting with the other IFMIS modules, we can improve monitoring on the public expenditure, prioritization of budgeted activities and enhance transparency in the budgeting process. Electronic budgeting can assist managers and other decision makers in the public sector to have adequate information which is timely, accurate and consistent for budgetary processes.

Automated cash management and public expenditure management have a significant positive relationship. The outcomes of automated cash management on public expenditure management was explained by three elements as follows; the system has reduced fraudulent transactions in accounts sector and has improved quality of the accounting system in the Ministry, the second one is that the system has improved on the managerial decision making in the accounts and linkage with other units in the Ministry for better service delivery in the accounts department and the third one is that the system has improved the payment processes and reduced misuse of public funds.

IFMIS supports financial reporting, policy decision making, fiduciary responsibilities and preparation of auditable financial statements. The generated reports can be used for various managerial purposes like decision making, track status of debts and receivables, monitor financial management among other activities in the accounting unit. Automated cash management can enhance confidentiality, integrity, availability and control of data. This assists in improving fraud detection and audit trail of all accounting processes.

\section{Conclusion}

Based on the study findings, linking of the electronic procurement with other IFMIS modules such as electronic budgeting and automated cash management can increase the system controls on public expenditure and reduce misuse of public funds. According to the findings of this study, Kenyan IFMIS modules are inadequately interlinked and there is need to improve on the entire system. Full implementation and interlinking of IFMIS modules can curbed unplanned expenditure on procurement leading to improved quality of procurements done since the system can easily generate the procurement plans to be adopted by various units in the public sectors for procuring purposes. Adoption and interlinking of electronic procurement can enhance transparency in the procurement process to a greater extent.

Linking electronic budgeting with other IFMIS modules has the greatest effect on public expenditure management. This is due the fact that the budget implementers can be able to trace a given allocation to various projects and rate the extent at which they are being undertaken thereby enhancing monitoring and evaluation of the same. Automated cash management improves the accounting reporting in the public sector. This is possible because the system can easily generate various reports using the inbuilt commands. Automated cash management system promotes timely accounts processes, accountability, transparency, integrity, confidentiality and accuracy of accounts the public sector.

\section{Recommendations}

Kenya should link various IFMIS modules used in the National government and County governments to enhance system controls and monitoring of various activities undertaken by various government units. System integration for the modules should be fast-tracked and administered from a centralized destination by an independent personnel. This would reduce the extent at-which an authorized budget shifting occurs at different departments and Ministries. There is need to increase awareness of the integrated system applications so as to ensure each public officer is interacting with the system on daily basis.

The government should increase the amount of resources for the system implementation and further monitoring of its operations. This would also enhance system controls which would reduce unauthorized transactions and improve on public expenditure management in Kenya. The study suggests that a further research should be undertaken to evaluate other factors affecting smooth implementing IFMIS in Kenya and their impact on the overall financial management in the public sector.

\section{Reference List}

Allen, B., Heurtebise, A. \&Tumbull, J. (2010). Improving Information Access. Business Management4 (3), 443 478.

Auditor General, (2015). Summary of the Report of the Auditor-General on the Financial Statements for Ministries, Departments, Commissions, Funds and other Accounts of the National Government for the year 2013/2014 Republic of Kenya. Retrieved from http://www. kenao.go.ke/

Bailey, S.K., (1968).Objectives of the Theory of Public Administration. Theory and Practice of Public Administration.128-139; the American Academy of Political and Social Science. Philadelphia

Baral, R., \&Rajan, R., (2015). Adoption of ERP system. An Empirical Study of Factors Influencing the Usage of ERP and its impact on the End User. IIMB Management Review 27. 105-117.

Chado, H.M., (2015). The Effect of Integrated Financial Management Information System on the Financial 
Management of Public Sector in Kenya

Dauda, S. \& Ibrahim, S.G., (2014). Globalization and the emergence of Government Integrated Financial Management Information System (GIFMIS). The Nigeria's experience. Journal of Economist and International Business Research (JEIBR) 2(3), 37- 47

Davis, Fred, Gordon, B., Michael, G., Morris, Venkatesh \&Viswanath (2003).User Acceptance of Information Technology; Toward a Unified View.MIS Quarterly, 27, 425-478

Di Benedetto, A. (2010). Diffusion of innovation. Encyclopedia of Technology and Innovation Management, 113116.

Dodd, F., (2010). The Dodd - Frank Wall Street Reform and Consumer Protection Act

Gounaris, S. \& Koritos, C., (2008). Investigating the Drivers of Internet Banking Adoption Decision: A Comparison of Three Alternative Frameworks. International Journal of Bank Marketing, 26(5), 282-304.

Hang, G., (2015). China Moves Ahead on Accrual Accounting.

Hendriks, C. (2012). Integrated Financial Management Information System: Guidelines for effective implementation by the public sector in South Africa.SA Journal of Information Management 14(1), 2-3.

Hodess, R., (2009). The implementation of Integrated Financial Information Management Systems (IFMIS)

Imbuye, F., (2013). Factors Influencing the Use of IFMIS in Public Sector, A case study of selected government Ministries in Kenya. Research Study, Nairobi, Kenya. http://ir-library.ku.ac.ke/handle/123456789/6283

Karanja, J.G. \&Ng'ang'a, E.N., (2014). Factors Influencing Implementation of Integrated Financial Management Information System in Kenya Government Ministries. Research Journal of Finance and Accounting 5(7)

Kimanzi, K. \& Njonde, J.N., (2014). Effect of Integrated Financial Management Information Systems on the Performance of Public Sector. A case of Nairobi County Government. International Journal of Social Studies and Entrepreneurship, 1(12), 913-936.

Kinyeki, J., Kipsang S.W., Peterson, S., (2008) \&Ndung'u (2006). Computerizing Accounting Systems in Developing Bureaucracies. Lesson from Kenya, Public Budgeting and Finance, 16(4),45

Li, Yu-hui, (2008). An Empirical Investigation on the Determinants of E- Procurement Adaptation in Chinese Manufacturing Enterprises.

Muigai, E., (2012). The Effect of Integrated Financial Management Information Systems on the Financial Management of Public Sector in Kenya. A case study of the Kenyan Ministries.

Ngibuini, E., (2005). Impact of Integrated Financial Management Information Systems. Unpublished Masters Desertion, University Of Nairobi.

Odoyo, F.S., Penina, A., \& Chumba, S. (2014). Integrated Financial Management Information System and its Effect on Cash Management in Eldoret West District Treasury, Kenya. International Journal of Business and Social Science, 5(8), Center for Promoting Ideas, USA

Orodho, J. A., (2008). Techniques of writing research proposals \& reports in education and social sciences. Nairobi. Kanezja HP Enterprises.

Pettijohn, C.D. \& Grizzle, G.A., (1997). Structural Budget Reform. Does it Affect Budget Deliberations; Journal of Public Budgeting, Accounting and Financial Management (9)1 26-45

Robinson, L. (2009). A summary of diffusion of innovations.

Rodgers, E. (1962). Diffusion of Innovations. 1st and 4th Ed. The Free Press. New York, London, Toronto, Sydney, Tokyo, Singapore.

Rogers, E.M., (1995). Diffusion of Innovations ( $4^{\text {th }}$ Ed.). The Free Press. New York, London, Toronto, Sydney, Tokyo, Singapore.

Rogers, E.M., (2003). Diffusion of innovations ( $5^{\text {th }}$ Ed.). Free Press. New York, London, Toronto, Sydney, Tokyo, Singapore.

Westland, C., \& Clark, T. (2000). Theory and Case Studies. Global Electronic Commerce.

Yonazi, J., (2010). Enhancing Adoption of E- Government Initiatives in Tanzania. 